We make the greatest progress and most

advantageous discoveries in this life not

from our successes but from our

mistakes. One crucial way to identify

them is to have the input of others, one

form of which is through intelligent, balanced and informed debate

\section{What I think is...}

Opinion is a great thing. We British often apologise for having one, on whatever subject happens to be under discussion. This results in us often beginning a sentence with something like, "well, this is only my opinion of course, but what I think is..." or, similarly "well, I'm sorry, but I disagree..." and so forth.

However, while we are not always very vociferous in expressing our point of view, we are for the most part in complete agreement that each one of us, within certain legal limitations, has the absolute right to hold and express that opinion. Unless it seems, in scientific circles, it is 'wrong. In that case we are not allowed to hold it or more pertinently, express it. We might all 'know' that the world is round, thanks to observation and scientific validation of that observation and so hold that people who believe otherwise are wrong. They may be wrong about the fact but are they wrong in holding their opinion?

I raise this question because I believe that a publication such as the $B D J$ has a duty to provide a forum for opinions. With some 20,000 plus readers twice a month where better to hold a debate on such a regular and on-going basis about matters that affect our chosen profession, daily work and patient care?

In this issue you will read two letters referring to a book review on a volume about ozone therapy in dentistry. The review, published in the $B D J$, was glowing. It was the opinion of the reviewer. The two letters point out that the reviewer, in the opinion of the correspondents, is 'wrong'. One letter goes further and suggests that therefore it was also 'wrong' to publish it. I fundamentally disagree. In this instance, I wonder how many readers do know that two recent reports suggest that ozone is not as effective as might have been hitherto reported or claimed? If they did not, from where else might they have found out and how else might the debate have been initiated?
Also in this issue you will find an 'Opinion' piece written by John Mew. In orthodontic circles in particular and in the wider world of dentistry in general, John Mew's views have for many years been controversial. Indeed it led him to complain earlier this year that on the verge of retirement he found himself, "excluded, suppressed and rejected by the UK establishment". ${ }^{1}$ A lot of readers may not agree with his views, some of you (perhaps many of you) will I hope be stimulated to write to me about them either to 'put the record straight' or to further the debate by expressing your own opinions. This is my hope because I think it important that we have such important debates out in the open.

If we are to continue to grow as a profession and keep up with changes, especially in such a fast moving world, we have to take a rather more adult stance on the opinions of others. We can no longer afford the luxury of whispering in corridors, muttering politely behind our hands or simply pretending that certain matters with which we disagree, or that we find personally distasteful, or think are scientifically wrong do not exist.

We make the greatest progress and most advantageous discoveries in this life not from our successes but from our mistakes. One crucial way to identify them is to have the input of others, one form of which is through intelligent, balanced and informed debate. We can have such debates on these pages providing evidence of our robustness as the profession of the art and science of dentistry, and where, most importantly, the expression of views will be open for all to read and to comment upon.

That's what I think. What do you think?

\section{Stephen Hancocks OBE, Editor in Chief} doi: 10.1038/sj.bdj.4812850

1. Interview. British Orthodontic Society News. April 2005. 